\title{
EXTRATERRESTRIAL SPHERULES IN THE SURROUNDINGS OF KAALI METEORITE CRATERS (SAAREMAA ISLAND, ESTONIA)
}

\section{Svetlana SHYMANOVICH, ${ }^{a}$ Tatyana KOLOSOVA, ${ }^{a}$ Anto RAUKAS, ${ }^{b}$ and Reet TIIRMAA}

a Акадэмія навук Беларусі, Інстытут геалогіi, геахіміi i геафізікі (Institute of Geology, Geochemistry and Geophysics, Belarus Academy of Sciences), Жодінская 7, 220141 Мінск, Беларусь (Belarus)

b Eesti Teaduste Akadeemia Geoloogia Instituut (Institute of Geology, Estonian Academy of Sciences), Estonia pst. 7, EE-0100 Tallinn, Eesti (Estonia)

Received March 3, 1993; accepted March 23, 1993

Abstract. The surroundings of meteorite craters are excellent areas for studying structural peculiarities of meteoric and meteoritic particles as well as micrometeorites. Three main types of extraterrestrial matter, namely meteoritic iron, meteoritic dust, and impactites, occurring in the surroundings of the Kaali meteorite crater were studied with a scanning electron microscope. The aim of this study is to contribute to our knowledge of extraterrestrial spherules in order to facilitate their differentiation from magnetic spherules generated by industrial pollution.

Key words: extraterrestrial spherule, meteorite crater, Estonia.

\section{INTRODUCTION}

Extraterrestrial spherules have been recovered from various terrestrial environments, most notably from deep-sea sediments and glacial ice. They have also been found in various amounts from ancient sediments. The oldest palaeometeoritic matter known in Estonia so far has been recovered in the Viru-Roela borehole in the central part of the country where it was enclosed in the Lower-Cambrian sandstone at a depth of $320 \mathrm{~m}$ (Viiding, 1965). The surroundings of meteorite craters (e. g. Kaali) and the regions of meteorite showers (e. g. Sikhote Alini), where most of the pulverized matter is undoubtedly extraterrestrial in origin, are the best environments for studying structural peculiarities of meteoric and meteoritic dust particles as well as micrometeorites. Cosmic spherules from the surroundings of the Kaali crater have recently been studied by several authors, in particular by Tiirmaa (1984, Тийрмаa, 1988). The present paper was initiated and compiled by A. Raukas. The study material was collected and prepared by R. Tiirmaa. S. Shymanovich and T. Kolosova from the Institute of Geology, Geochemistry and Geophysics of the Belarus Academy of Sciences made morphological and geochemical analyses.

\section{SHORT CHARACTERIZATION OF THE STUDY AREA}

Eight meteorite craters are to be found at Kaali on the island of Saaremaa, $19 \mathrm{~km} \mathrm{NE}$ of the town of Kuressaare. The diameter of the main crater is about $110 \mathrm{~m}$ and its depth is $16 \mathrm{~m}$. The idea that the craters were of cosmic origin was first advanced by Kalkun-Kaljuvee in 1919 (Kalkun 1922, Kaljuvee 1933), although it was only proved by Reinvald in 1937. Aaloe and Tiirmaa (Аалоэ \& Тиймаa, 1981) pointed out that the soil both in the Kaali craters and around them contains, apart from meteoritic fragments, great amounts of pulverized and partly metamorphosed meteor- 

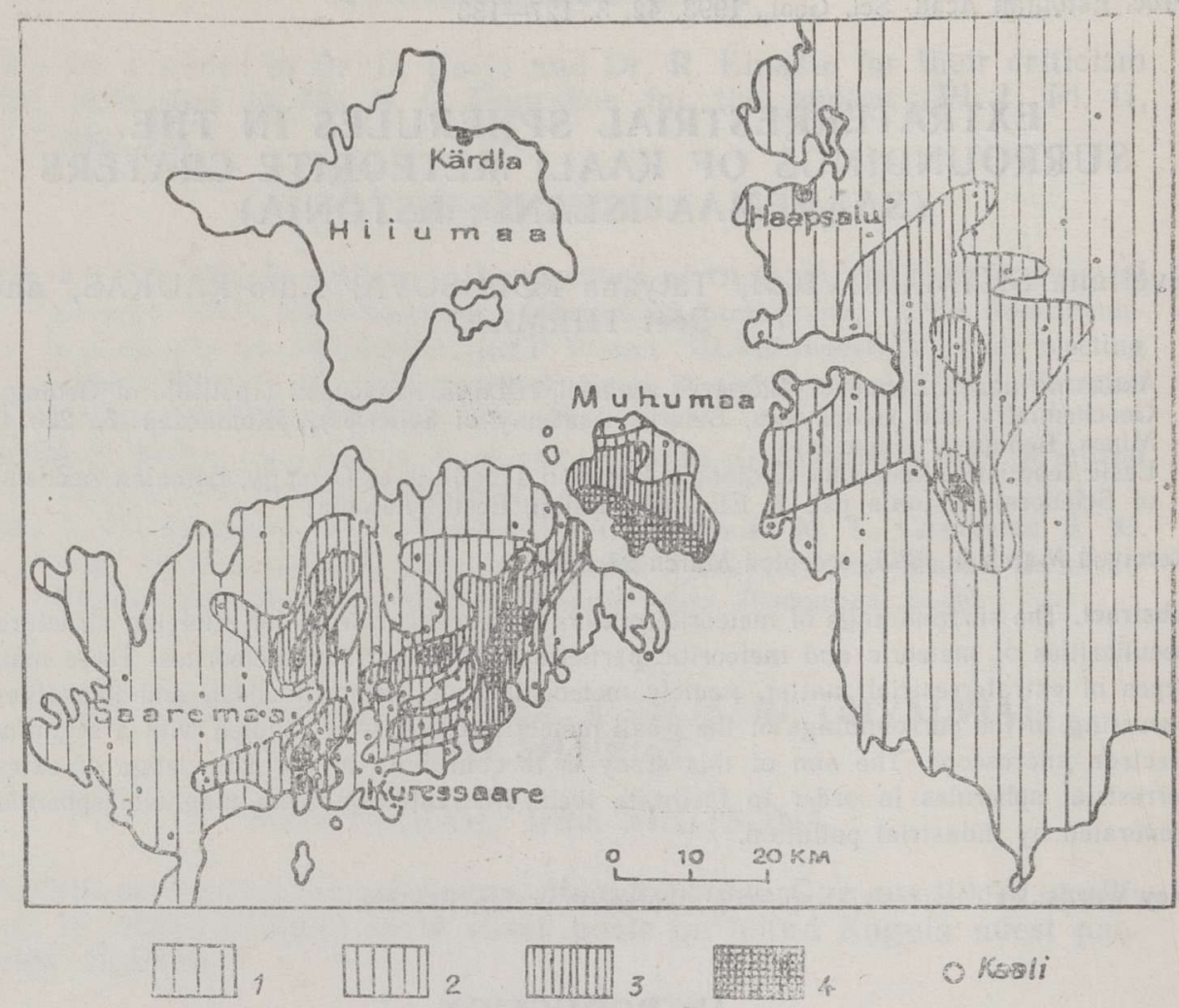

Location of sites with pulverized meteoritic matter on the islands of Saaremaa and Muhumaa, and on the West-Estonian mainland according to Tiirmaa (Тийрмаa, 1988) with modifications: $1-<10 ; 2-10-20 ; 3-20-40 ; 4-40-60\left(\mathrm{~g} / \mathrm{m}^{3}\right)$.

itic matter generated as a result of the impact. Tiirmaa (1984, Тийрмаa, 1988) demonstrated that areas with elevated concentrations of meteoritic matter also occur east of Kaali, and even on the Estonian mainland (Fig.), showing clearly the projection of the supposed fall trajectory. According to Tiirmaa, the main body of the meteorite must have disintegrated in the east, not far from the present Lake Kaali. Quantitative calculations show that in the Kaali area considerable masses of meteorite matter occur in the ground (Tiirmaa, 1984). The explosion parameters suggest that the initial mass of the Kaali meteorite must have been somewhere between 400 and 1000 tons (Бронштейн \& Станюкевич, 1963). Taking the area with a high spherule concentration equal to $c .500 \mathrm{~km}^{2}$ and the mean content of cosmic matter $50 \mathrm{~g} / \mathrm{m}^{3}$, the initial mass of the meteorite should have been 2500 tons (Tiirmaa, 1984). However, operating with more realistic values: $2000 \mathrm{~km}^{2}$ for the area and $20 \mathrm{~g} / \mathrm{m}^{3}$ for the mean cosmic matter content, we obtain 10000 tons for the initial mass of the meteorite (Тийрмаа, 1988). It is assumed that meteoritic dust along with cosmic dust makes up the largest part of the cosmic matter falling onto the Earth (Krinov, 1976).

\section{METHODS}

Samples, each $4-6 \mathrm{~kg}$ in weight, taken from a depth of $30-45 \mathrm{~cm}$, were washed to remove humus, plant remains, and clay particles (Тийpмаa, 1988). After sieving (diameter $5 \mathrm{~mm}$ ) and magnetic separation, 


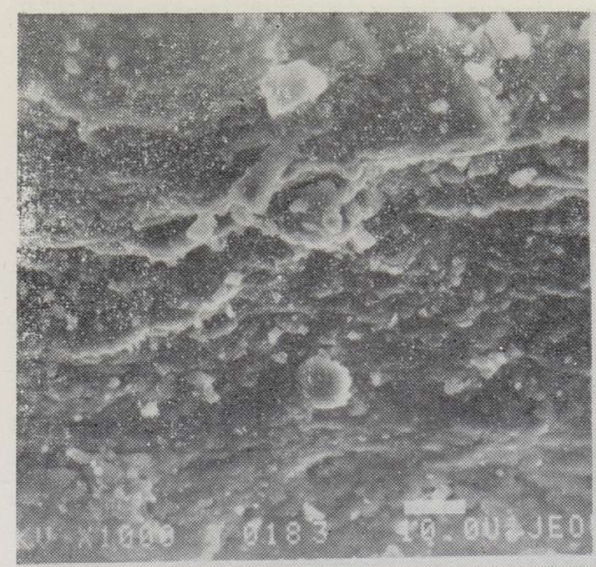

1

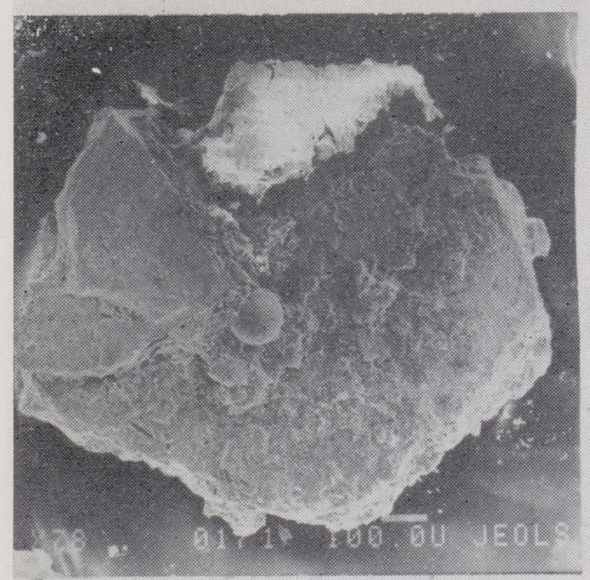

3

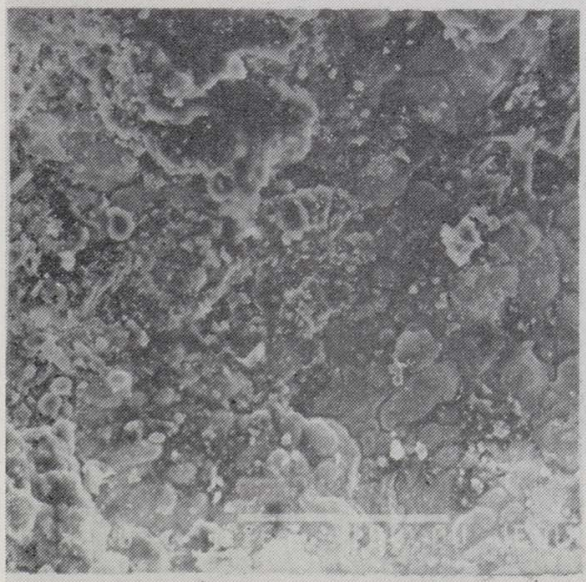

5

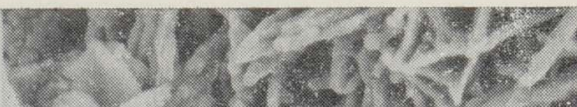

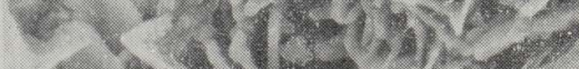

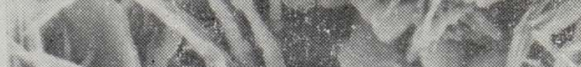

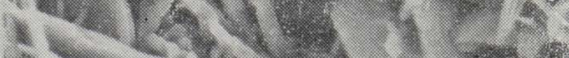

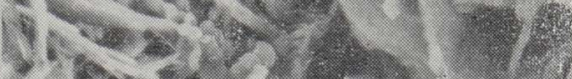

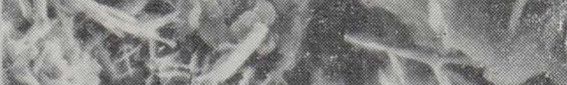

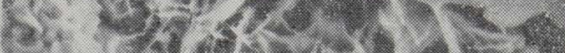

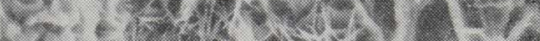

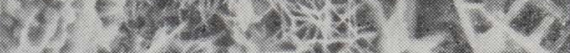

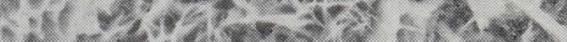

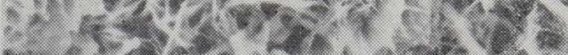

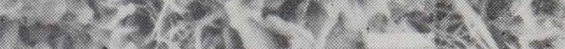

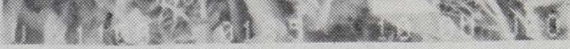

2
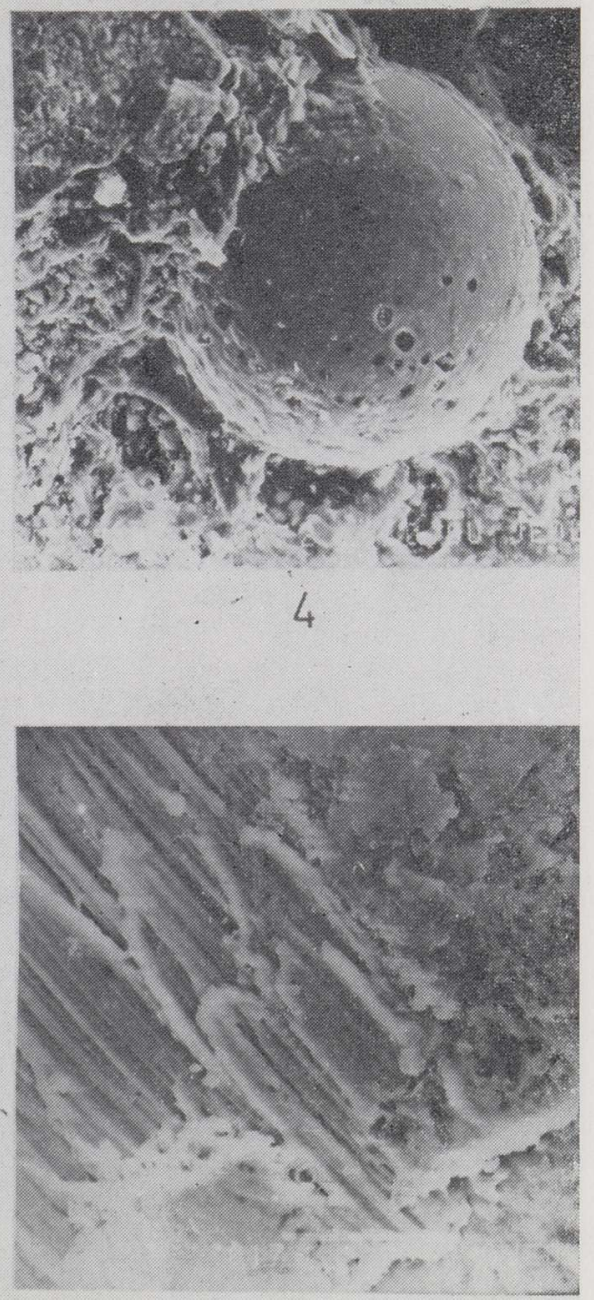

6 


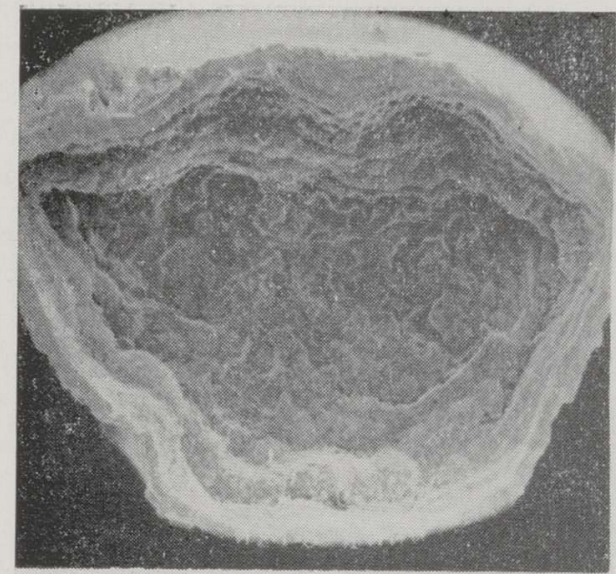

7

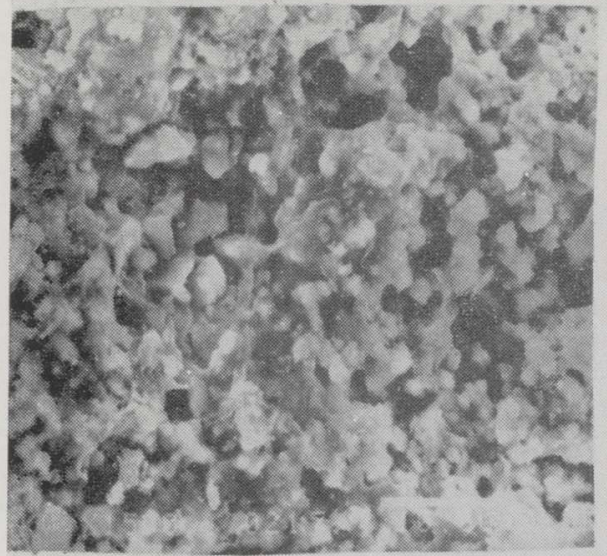

9

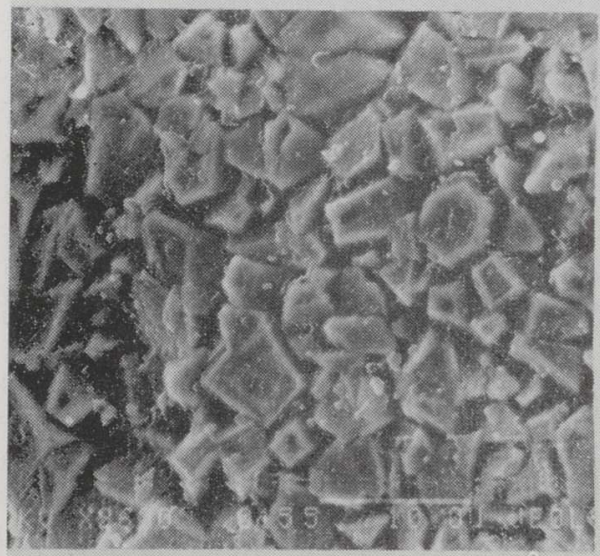

11

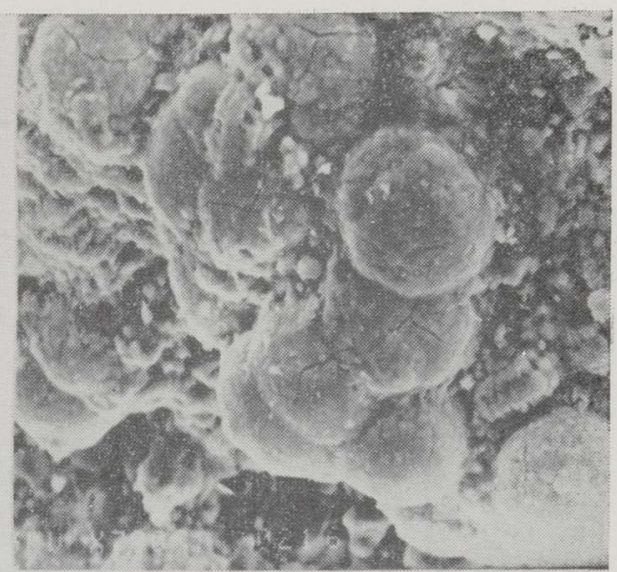

8

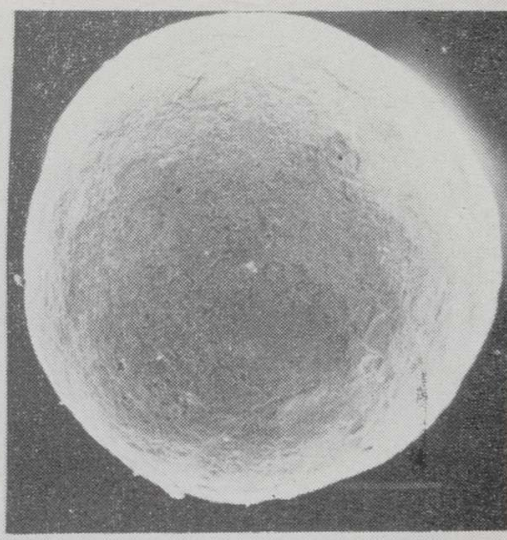

10

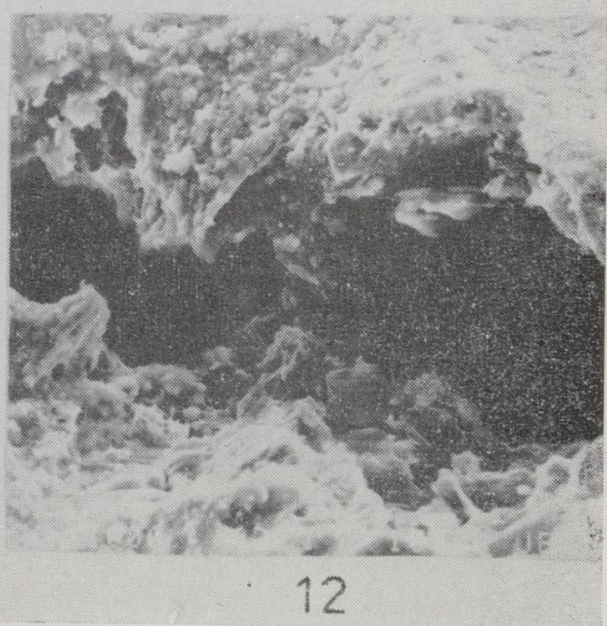




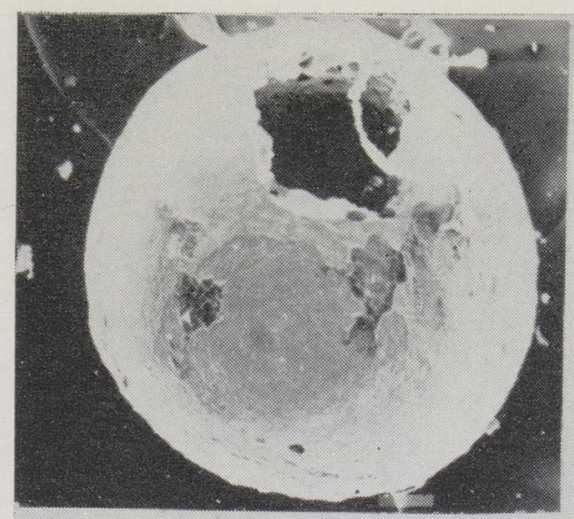

13

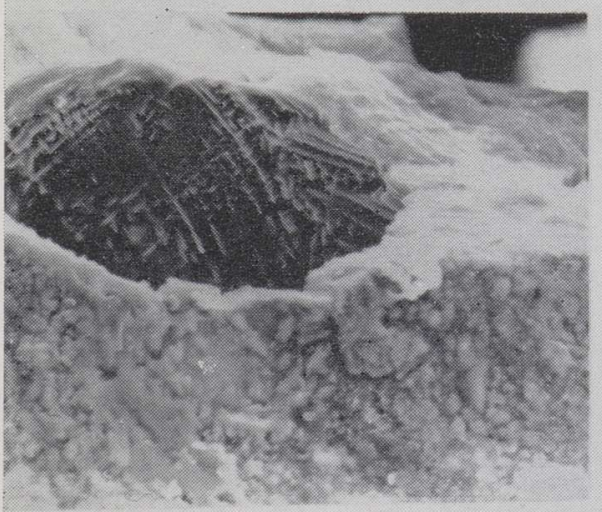

15

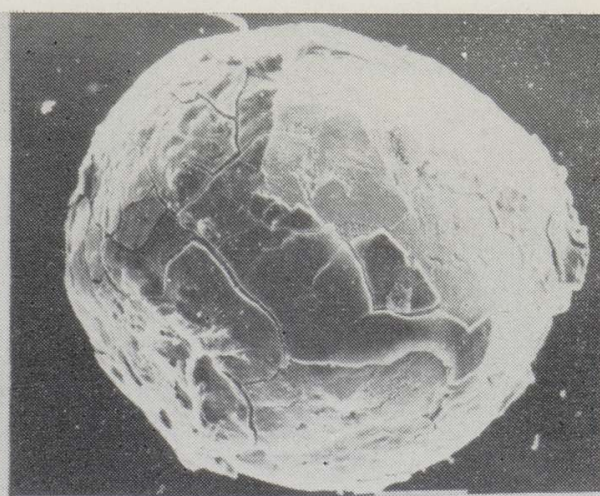

14

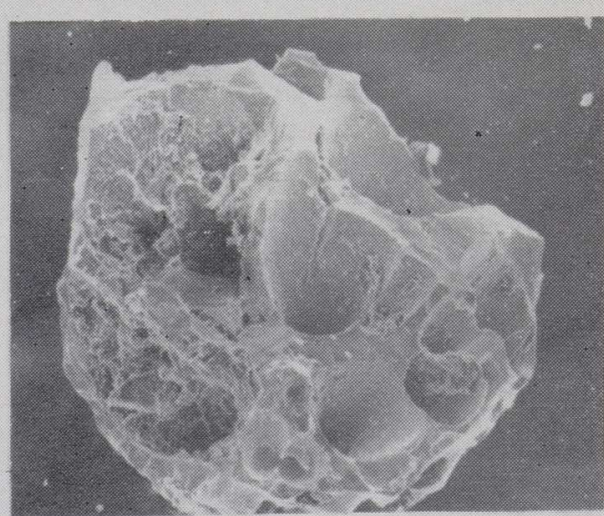

16

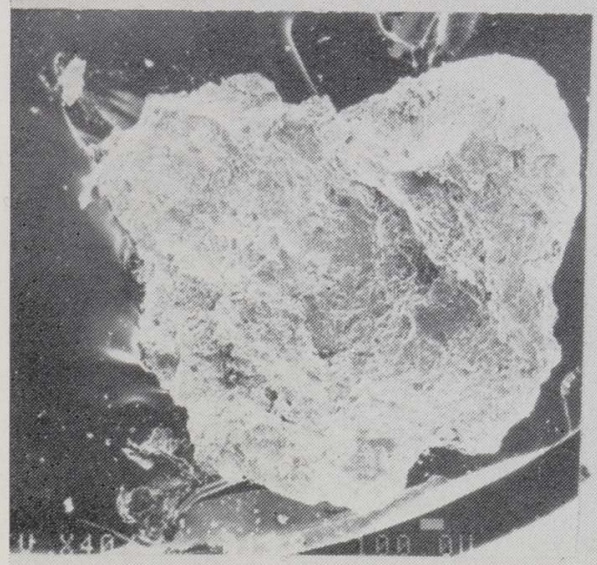

17

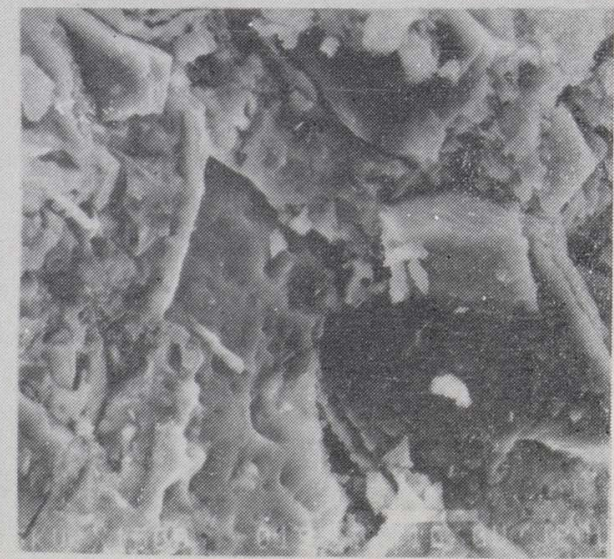

18 


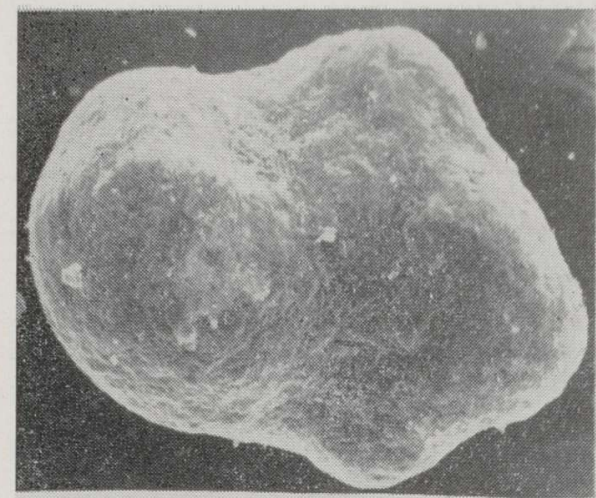

19

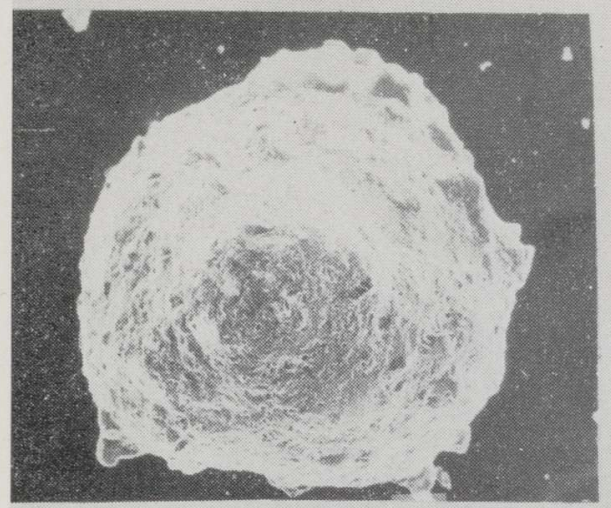

21

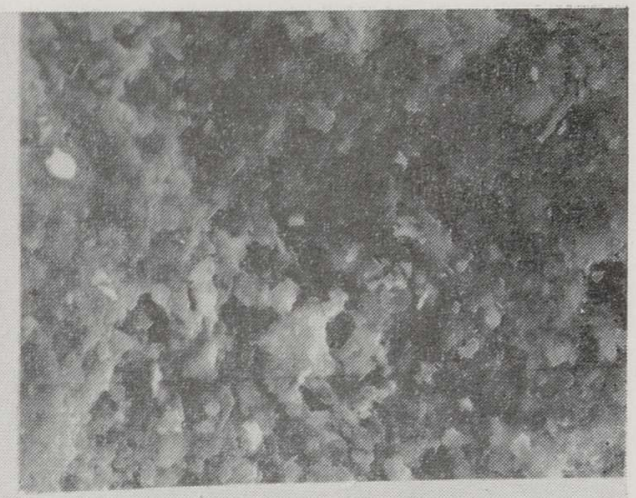

20

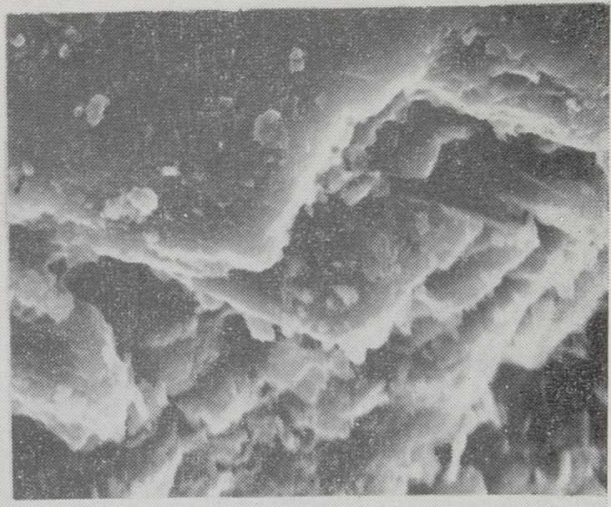

22
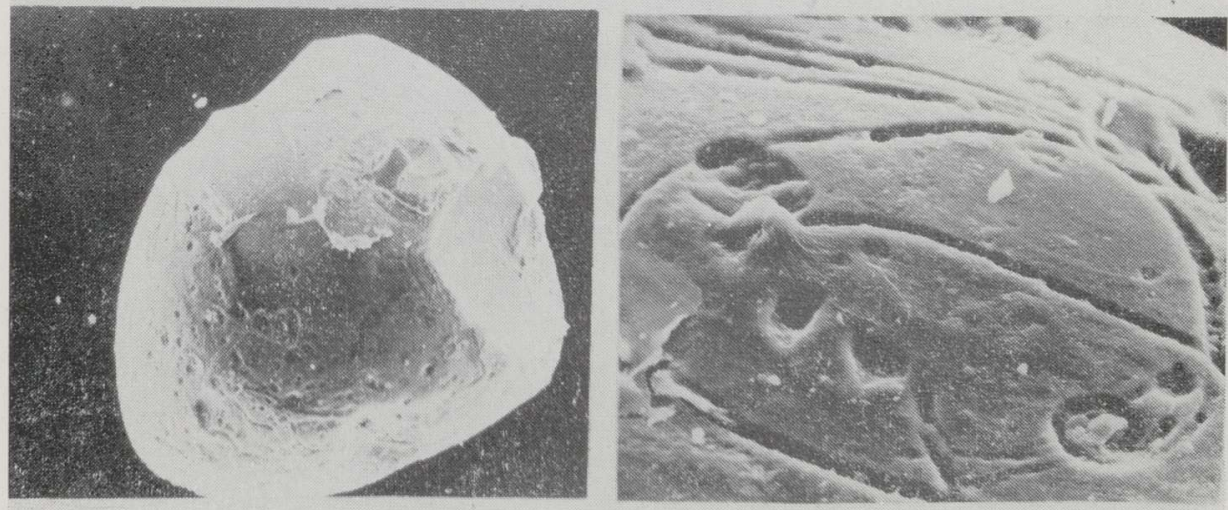

23

24 
meteoritic particles were collected under a binocular microscope and weighed. Their concentration in soil was determined to find out the direction of the meteorite fall and the initial mass of the meteorite body. The meteorite matter was studied by means of a scanning electron microscope Jeols ISM-35C and microsonic equipment POM-100Y.

\section{CLASSIFICATION OF EXTRATERRESTRIAL SPHERULES}

Krinov (1976) distinguished three forms of pulverized cosmic matter: meteoritic dust, meteoric dust, and micrometeorites. Meteoritic dust consists of sharply angular and, in general, irregular tiny fragments, formed as a result of the break-up of meteorite masses at the moment of their impact with the ground. Their sizes vary from several microns to a few millimetres. Meteoric dust consists of magnetic spherules, drop-like particles, with an average diameter of $30-40 \mu \mathrm{m}$. Most of the spherules have porous inner structure. Micrometeorites are minute meteorites covered with a fusion crust. Regmaglypts are sometimes found on their surface. All the above-mentioned types of extraterrestrial pulverized matter were recovered in the Kaali area. The major part of the pulverized matter con-

Photo 1. Fluidal texture of micrometeorite surface (magnification $\times 1000$ ).

Photo 2. Honeycomb texture of manganiferous and gypsum oxide segregations on the surface of micrometeorite. General view (magnification $\times 1100$ ).

Photo 3. Micromorphology of a sharp-edged microfragment of meteorite. General view (magnification $\times 78$ ).

Photo 4. Fragment of microparticle shown in Photo 3 (magnification $\times 540$ ).

Photo 5. Flake-like ferruginous formations on the surface of a meteor:te microfragment (magnification $\times 360$ ) .

Photo 6. Rod-like surface of meteorite microfragment (magnification $\times 3000$ ).

Photo 7. Microtexture of layered crust coating a meteorite microfragment (magnification $\times 24)$.

Photo 8. Vesicle-rich layer (second from top) of the micrometeorite shown in Photo 7 (magnification $\times 780$ ).

Photo 9. Interior of a micrometeorite with irregular fragments, shown in Photo 7 (magnification $\times 1500$ ).

Photo 10. Typical rounded hollow magnetite globule (magnification $\times 180$ ).

Photo 11. Fragment of magnetite globule surface with tetra- and trihedral texture (magnification $\times 8600$ ).

Photo 12. Surface of the magnetite globule with irregular holes (magnification $\times 1000$ ).

Photo 13. Rounded magnetite globule with metal core (magnification $\times 94$ ) .

Photo 14. Ellipsoidal magnetite globule with conchoidal mantle (magnification $\times 160$ ).

Photo 15. Fragment of the core surface with the widmanstatten structure of globule, shown in Photo 14 (magnification $\times 1800$ ).

Photo 16. Remains of a spherule, rounded or ellipsoidal in shape with crater-like funnels (magnification $\times 150)$.

Photo 17. Magnetite platelet, irregular in form, with kidney-shaped striated surface. General view (magnification $\times 40$ ).

Photo 18. Imbricate rhombic surface of magnetite platelet with a pattern of rhombs and polyhedrons (magnification $\times 1500$ ) .

Photo 19. Partly melted magnetite platelet with smoothed edges (magnification $\times 180$ ). Photo 20. Fragment of flow surface of melted magnetite platelet displaying vesicles and caverns (magnification $\times 1600$ ).

Photo 21. Magnetite-silicate impactite with tubercular surface (magnification $\times 94$ ). Photo 22. Angular-imbricate surface of magnetite-silicate impactite (magnification $\times 1300$ ). Photo 23. Drop-like silicate impactite (magnification $\times 120$ ).

Photo 24. Surface fragment of the silicate impactite shown in Photo 23 (magnification $\times 1000$ ) 
sists of micrometeorites and their microfragments (Аалоэ \& Тийрмаа, 1981). However, meteoritic dust prevailed in some parts of the study area. In the Kaali area, Aaloe and Tiirmaa ( Аалоэ \& Тийрмаa, 1981) identified the following types of extraterrestrial matter:

1. Meteoritic iron (micrometeorites and their microfragments);

2. Meteoritic dust

a) magnetic globules formed on the melting of meteoritic matter during the impact, or from condensed metal vapour;

b) magnetic platelets formed from heated kamacite along the cracked surfaces;

3. Impactites

a) magnetic-silicate impactites, formed on the mixing of the terrestrial silicate matter with the meteoritic iron that melted during the explosion. This type includes spherical or irregular ianites and crusts;

b) silicate globules and irregular porous microirgisites, formed from molten or vaporized silicate minerals during the explosion.

The above classification with some modifications has been used in this paper.

\section{DESCRIPTION OF THE NEWLY DISCOVERED SPHERULES}

\section{Meteoritic iron}

Micrometeorites and their microfragments (less than $1000 \mu \mathrm{m}$ ) are covered with a fusion crust with, regmaglypts sometimes found on their surface. Their average content at Kaali is $150-300 \mathrm{mg} / \mathrm{m}^{3}$ of soil (Аалоэ \& Тийрмаa, 1981).

Micrometeorites are irregular in form, with smooth edges and corners. Their concave surfaces exhibit traces of fusion and occasional rust spots. Scanning electron microscopy views show marked fluidal projections (Photo 1) and secondary transformations on their commonly undulate flow surface. Notable is the bristly, tracery or reticulate, sometimes honeycomb texture of manganiferous and gypsum segregations locally developed on their surfaces (Photo 2). According to Shoba and Balabko (Шоба \& Балабко, 1983), similar segregations of manganese compounds are common for many neocrystallizations in the soils of the forest zone.

Microprobe analysis has shown that the predominant element in the micrometeorites is $\mathrm{Fe}$ with accessory concentrations of $\mathrm{Ni}, \mathrm{Si}, \mathrm{Al}$, and $\mathrm{Cl}$.

The content of tiny fragments of micrometeorites in the craters and surrounding soil is more than $1 \mathrm{~g} / \mathrm{m}^{3}$. Morphologically, two varieties are distinguished:

(1) sharp-edged angular forms (Photo 3) with uneven microgranular surfaces. This variety includes cupola-like and spherical forms (Photo 4) abounding in rounded pores which either penetrate through their thin walls or are filled with fine material;

(2) irregular, sometimes elongated forms with uneven margins and cracks. Some of those forms have flocculent clusters (Photo 5) with diffusive edges on their surfaces, while the columnar surface of others displays a clear pattern of oblong chip-like formations (Photo 6).

Microfragments are usually strongly oxidized and crusted with a thin layer of loamy material cemented with iron hydroxide. Often the crust weighs more than the fragment itself. The crust consists of several layers differing in structure (Photo 7):

(1) undulating occasionally smooth with a series of parallel fissures and larger cracks of different orientation, with small vesicular formations; 
(2) big vesicles creating a specific pattern and forming clusters, which are sometimes cut by cracks. Besides big vesicles there occur numerous small ones, irregular in form (Photo 8);

(3) shapeless fragments, rarely spherical, fill in the interior of the fragment (Photo 9). The boundaries between layers are marked or diffused.

According to microprobe analysis, the predominant element is $\mathrm{Fe}$ with an admixture of $\mathrm{Si}$ and $\mathrm{Ni}$. $\mathrm{Ca}, \mathrm{K}$, and $\mathrm{Al}$ occur in low concentrations.

\section{Meteoritic dust}

Meteoritic dust is mainly concentrated in the debris of the craters and in the soil around them. It is rather difficult to separate it from meteoric dust, which is formed during the movement of meteoric bodies in the atmosphere, and slowly precipitates onto the Earth's surface over a vast territory. We have differentiated magnetite globules and magnetite platelets in our collection.

Magnetite globules vary in roundness, internal structure and microsculpture. They may be spherical, rounded (Photo 10), elliptic, ovatetubercular, oolitic or drop-like, resembling a lemon. Occasionally, strongly crushed forms are encountered. In all likelihood, these are remains of rounded or elliptic globules.

In terms of internal structure the following forms can be distinguished:

(1) hollow (Photo 10) magnetite globules. Their surface is covered with small rod-like or irregular plates, which most frequently are hexahedral, tetrahedral, or trihedral in outline (Photo 11). Holes in the surface are irregular with uneven margins (Photo 12). Rounded or elliptic globules have sometimes a conchoidal mantle (Photo 13);

(2) compact globules with metallic nucleus (Photo 14), whose uneven surfaces have small irregular kidney-shaped or drop-like projections. The nuclei vary in appearance. They may have widmanstatten structures (Photo 15 ) or be rod-like (elongated), resembling a prism structure;

(3) hypothetically rounded forms with extraordinarily interesting surfaces covered with a pattern of regular rounded moonlets resembling craters (Photo 16).

The predominant element found in magnetic globules is $\mathrm{Fe}$ with accessory concentrations of $\mathrm{Si}, \mathrm{Ca}$, and $\mathrm{K}$. The concentration of $\mathrm{Al}$ is low.

According to Viiding (1965), meteoric dust in the Estonian bedrock consists of magnetite-iocite globules $(\varnothing 20-450 \mu \mathrm{m})$ or shell-like fragments ( $\varnothing$ up to $2-3 \mathrm{~mm}$ ). The content of $\mathrm{Ni}$ is below $1 \%$.

Magnetite globules were recovered in different amounts in all soil samples collected both in the crater and beyond its boundaries (Аалоэ \& Тийрмаa, 1981). Their mean content is $2-3 \mathrm{mg} / \mathrm{m}^{3}$ of soil, and the sizes range from 5 to $1000 \mu \mathrm{m}$. The dark grey or bluish-grey surfaces of magnetite globules have metallic lustre.

Magnetite platelets are usually less than $1000 \mu \mathrm{m}$ (occasionally up to $2000 \mu \mathrm{m})$ in diameter, and $100-200 \mu \mathrm{m}$ thick. Generally, they are dull grey, sometimes with metallic lustre. Most frequently they are irregular in outline (Photo 17) and have kidney-shaped striated or imbricate surfaces displaying a pattern of rhombs, quadrangles, and polyhedrons (Photo 18). The predominant element is Fe with accessory concentrations of $\mathrm{Ni}$ and $\mathrm{Cl}$. The concentration of $\mathrm{Si}, \mathrm{K}$, and $\mathrm{Al}$ is low.

Occasionally, partly melted platelets with smoothed edges are encountered (Photo 19). Their undulate surfaces display traces of vesicles and caverns (Photo 20) and fragments of crushed material (or flakes of newly formed Fe and Mn oxides). Magnetite platelets have been recovered both in the craters and around them. However, their genesis is not yet entirely clear. 


\section{Impactites}

Impactites, representing the products of impact metamorphism, are small and comparatively rare in the Kaali region. Both magnetite-silicate (ianite) and silicate formations have been discovered. The concentration of ianites in the study area ranges from 10 to $50 \mathrm{mg} / \mathrm{m}^{3}$, but in the vicinity of small craters it may exceed $200 \mathrm{mg} / \mathrm{m}^{3}$. The abundance of silicate globules is usually less than $1 \mathrm{mg} / \mathrm{m}^{3}$ (Аалоэ \& Тийрмаа, 1981).

Uneven tubercular surfaces of ianites cemented with ferric oxides and hydrous ferric oxides (Photo 21) are common. At strong magnification they were seen to have cavernous-mixed-block, angular-imbricate (Photo 22 ), or striated structures. The predominant elements were $\mathrm{Si}, \mathrm{Fe}$, and $\mathrm{Al}$ with accessory concentrations of $\mathrm{Mn}$ and $\mathrm{K}$. The concentration of $\mathrm{Ca}$ was low.

The largest, subspherical ianite $(\varnothing 6600 \mu \mathrm{m})$ was found in the vicinity of crater No 5 (Аалоэ \& Тийрмаa, 1981). Ianites generally range from $350-1000 \mu \mathrm{m}$ in diameter. They are spherical, drop-like, ellipsoidal, biconvex, or irregular in form, and dark grey, sometimes bluish in colour. Ianites have a foamy inner structure.

In silicate globules, ellipsoidal, and drop-like forms (Photo 23) the diameter ranges from 5 to $20 \mu \mathrm{m}$. These forms are usually brownishyellow with smooth lustrous (occasionally dull) surfaces, pitted with odd furrows, which create an impression of rock paintings (Photo 24).

Microprobe analysis showed that $\mathrm{Si}, \mathrm{Fe}, \mathrm{Al}$, and $\mathrm{K}$ dominate in elemental composition with $\mathrm{Mg}, \mathrm{Ni}, \mathrm{Cl}$, and $\mathrm{Ti}$ being present in accessory concentrations.

\section{CONCLUSIONS}

The information obtained in studying meteoritic matter and impactites with an electron scanning microscope combined with chemical analysis help distinguish extraterrestrial material from magnetite particles of terrestrial origin (industrial dust). It also enables to establish some peculiarities of the formation and structure of these materials.

Morphologically, the variety and complexity of meteoritic matter are impressive. This is often due to secondary processes at the site where the matter is discovered. The morphology of meteoritic matter suggests that it has undergone phase transformation in the zone of hypergenesis. It is evident that changes in the surface and composition of the particles depend on the form and type of these particles. The chemical composition of magnetites and impactites differs in the concentration of both the prevalent ( $\mathrm{Fe}$ in magnetite; $\mathrm{Fe}, \mathrm{Si}, \mathrm{Al}$, and $\mathrm{K}$ in impactite) and accessory ( $\mathrm{Si}, \mathrm{Ni}, \mathrm{Al}$ in magnetite; $\mathrm{Mn}, \mathrm{Mg}$, and $\mathrm{Ti}$ in impactite) compounds. The microsculpture of meteoritic matter displays a great variety of origins and ages. The microstructural peculiarities help shed some light upon the genesis of the recovered meteorite or impactite material and the conditions under which their transformation took place.

\section{REFERENCES}

Kaljuvee, J. 1933. Die Grossprobleme der Geologie. F. Wassermann, Tallinn (Reval). Kalkun, J. 1922. Uldine geoloogia. Tallinn.

Krinov, E. L. 1976. Forms of nonterrestrial dust on the Earth. - Meteoritics, 11, 1, $43-50$.

Reinvald, I. 1937. Meteoorkraatrid Saaremaal. - Loodus, 1, 1-7.

Tiirmaa, R. 1984. Kaali meteoriidiainet otsimas. - Eesti Loodus, 9, 571-576.

Viiding, H. 1965. Vanima mẹtẹoorse tolmu lẹid Eestis, - Eestị Loodus, 5, 293-296, 
Аалоэ А., Тийрмаа Р. 1981. Распыленное метеоритное и импактное вещество на кратерном поле Каали. - Изв. АН ЭССР. Геол., 30, 1, $20-27$.

Бронштейн В. А., Станюкевич К. П. 1963. О кратерообразующих метеоритах. Тр. Ин-та геол. АН ЭССР, ХІ, 73-83.

Тийрмаa Р. 1988. Площадное распределение распыленного вещества метеорита Каали. - Изв. АН ЭССР. Геол., 37, 1, 43-46.

Шоба С. А., Балабко П. А. 1983. Микростроение и состав марганцово-железистых новообразований почв лесной зоны. - In: Микроморфологическая диагностика почв и почвообразовательных процессов. Наука, Москва, 21-33.

\title{
MAAVÄLISED METEORIITSED KERAKESED KAALI KRAATRIVÄLJA LÄHIKONNAS
}

\section{Svetlana ŠIMANOVITS̄, Tatjana KOLOSSOVA, Anto RAUKAS, Reet TIIRMAA}

Kaali meteoriidiväljal ja selle lähikonnas leidub pinnases rohkesti (keskmiselt $150-300 \mathrm{mg} / \mathrm{m}^{3}$ ) meteoriidikillukesi ja meteoriidi plahvatusel pihustunud ainest, mis on võimaldanud kindlaks määrata meteoriidi massi ja langemissuuna. Valdava osa pihustunud ainest moodustavad meteoriitraua osakesed, kuid palju on ka meteoriiditolmu (magnetiiditerakesi ja - plaadikesi). Harvem leidub magnetiitsilikaatseid ja silikaatseid impaktiite. Pihustunud meteoriitse ainese uurimine skaneeriva elektronmikroskoobi ja mikrosondi abil võimaldas esile tuua arvukaid morfoloogilisi erimeid. Saadud tulemused on olulised Kaali meteoriidi plahvatusprotsessi täpsustamisel, meteoriitse ainese muutuste uurimisel ja tehnogeensete magnetiidikerakeste ja -plaadikeste eristamisel looduslikest.

\section{ВНЕЗЕМНЫЕ ШАРИКИ В ОКРЕСТНОСТЯХ МЕТЕОРИТНЫХ КРАТЕРОВ КААЛИ (О-В СААРЕМАА, ЭСТОНИЯ)}

\author{
Светлана ШИМАНОВИЧ, Татьяна КОЛОСОВА, Анто РАУКАС, \\ Рээт ТИКРМАА
}

K настоящему времени известно, что разрушение основного тела Каалиского метеорита произошло в нескольких километрах восточнее Каали и преобладающая его масса распылена в рыхлых наносах ближайших окрестностей (Тийрмаа, 1988).

В статье представлены результаты изучения с помощью сканирующего электронного микроскопа и микрозонда морфологии поверхности обломков метеоритного железа (микрометеоритов и метеоритных микроосколков), метеоритной пыли (магнетитовых шариков и пластинок) и магнетито-силикатных и силикатных импактитов.

Полученные результаты позволяют не только отличить внеземные магнетитовые образования от техногенных, но и установить ряд особенностей строения метеоритного вещества и условий его формирования. Обращают на себя внимание разнообразие морфологического облика метеоритного вещества, сложность его микроскульптуры, зачастую обусловленных вторичными процессами. В морфологическом облике метеоритного вещества находит отражение стадийность его преобразования в зоне гипергенеза. Отчетливо выявляется наличие определенных закономерностей в изменении поверхности и состава в зависимости от формы и типа обломков. Химический состав магнетитов и импактитов различается относительным содержанием как главных компонентов (железа в магнетитах; железа, кремния, алюминия и калия в импактитах), так и второстепенных (кремния, никеля и алюминия в первых; марганца, магнезия и титана во вторых). 